\title{
Tulane
}

\author{
Tulane Economics Working Paper Series
}

\section{Scholars Who Became Practitioners: the Influence of Research on the Design, Evaluation and Political Survival of Mexicos Anti-poverty Program Progresa/Oportunidades}

\author{
Nora Lustig \\ Department of Economics \\ Tulane University \\ New Orleans, Louisiana \\ nlustig@tulane.edu \\ Working Paper 1123 \\ June 2011
}

\begin{abstract}
Celebrated by academics, multilateral organizations, policy-makers and the media, Mexicos Progresa/ Oportunidades conditional cash transfers program (CCT) is constantly used as a model of a successful anti-poverty program. Here I argue that the transformation of well-trained scholars into influential practitioners played a fundamental role in promoting a new conceptual approach to poverty reduction, ensuring the technical soundness and effectiveness of the program, incorporating rigorous impact evaluation, and persuading politicians to implement and keep the program in place. The involvement of scholarspractitioners also helped disseminate the new CCT technology to many countries around the world within a decade.
\end{abstract}

Keywords: anti-poverty programs, conditional cash transfers, scholars, practitioners, Progresa, Oportunidades, Mexico

JEL: Keywords: H3, H53, I3, O2 


\title{
Scholars Who Became Practitioners: the Influence of Research on the Design, Evaluation and Political Survival of Mexico's Anti-poverty Program Progresa/ Oportunidades
}

\author{
Nora Lustig $^{1}$ \\ June 2011
}

\begin{abstract}
Celebrated by academics, multilateral organizations, policy-makers and the media, Mexico's Progresa/Oportunidades conditional cash transfers program (CCT) is constantly used as a model of a successful anti-poverty program. Here I argue that the transformation of well-trained scholars into influential practitioners played a fundamental role in promoting a new conceptual approach to poverty reduction, ensuring the technical soundness and effectiveness of the program, incorporating rigorous impact evaluation, and persuading politicians to implement and keep the program in place. The involvement of scholars-practitioners also helped disseminate the new CCT "technology" to many countries around the world within a decade.
\end{abstract}

Key Words: anti-poverty programs, conditional cash transfers, scholars, practitioners, Progresa, Oportunidades, Mexico

JEL Codes: H3, H53, I3, O2

\footnotetext{
${ }^{1}$ Nora Lustig is the Samuel Z. Stone Professor of Latin American Economics at Tulane University and non-resident fellow at the Center for Global Development and the Inter-American Dialogue (nlustig@tulane.edu). An earlier version of this paper was prepared for the international workshop "Scholars, Practitioners, and Inter-American Relations," organized at the Center for International Studies, University of Southern California (USC), in Los Angeles, CA, on April 26-27, 2011. I am very grateful to Abraham Lowenthal and Mariano Bertucci for their useful comments on the earlier draft and to Samantha Greenspun for her invaluable research assistantship. All errors and omissions remain my sole responsibility.
} 


\title{
Scholars Who Became Practitioners: the Influence of Research on the Design, Evaluation and Political Survival of Mexico's Anti-poverty Program Progresa/ Oportunidades
}

\author{
Nora Lustig ${ }^{2}$
}

June 2011

\section{Introduction}

The largest anti-poverty program in Mexico's history, Oportunidades is a conditional cash transfer program (CCT) that targets rural and urban households living in extreme-poverty. ${ }^{3}$ Launched in 1997 as Progresa, the program changed its name to Oportunidades in early 2002, shortly after President Vicente Fox took office. Designed to complement traditional supply-side government spending in education and health (e.g., schools, teachers, hospitals, doctors, etc.), the demand-side subsidies (e.g., the cash transfers) in Oportunidades are meant to promote school attendance and health-care check-ups for poor children. The cash transfers help reduce poverty in the present and the conditions households must meet to receive the transfers help build the human capital of poor children. Thus, the program addresses short-term poverty and its inter-generational transmission concurrently.

Since its inception, Progresa/Oportunidades' design was influenced by academic research and has been subjected to numerous scholarly impact evaluation studies. These studies have helped improve the program's operational design and performance. More importantly perhaps, evidence of its success was one of the key factors that protected Progresa from being abolished with the change in government at the turn of the century. In December 2001, Vicente Fox became the first president elected from an opposition party--the $\mathrm{PAN}^{4}$-- in more than 70 years of $\mathrm{PRI}^{5}$-dominated politics. At the time, there were strong rumors that his newly appointed Minister of Social Development, Josefina Vázquez Mota, would replace Progresa with a different, charity-based poverty alleviation program. This was not surprising. Traditionally, Mexico’s anti-poverty initiatives tended to disappear with the sexenio ${ }^{6}$ even when the incumbent and the incoming presidents came from the

\footnotetext{
${ }^{2}$ Nora Lustig is the Samuel Z. Stone Professor of Latin American Economics at Tulane University and non-resident fellow at the Center for Global Development and the Inter-American Dialogue. An earlier version of this paper was prepared for the international workshop "Scholars, Practitioners, and Inter-American Relations," organized at the Center for International Studies, University of Southern California (USC), in Los Angeles, CA, on April 26-27, 2011. I am very grateful to Abraham Lowenthal and Mariano Bertucci for their useful comments on the earlier draft and to Samantha Greenspun for her invaluable research assistantship. All errors and omissions remain my sole responsibility.

${ }^{3}$ Lustig (2007).

${ }^{4}$ Partido Acción Nacional (National Action Party)

5 Partido Revolucionario Institucional (Institutional Revolutionary Party)

${ }^{6}$ The sexenio refers to the six year term limit on the Mexican presidency.
} 
same party and much of the same technocracy remained in place. This had happened, for example, with IMSS-COPLAMAR ${ }^{7}$ during the transition from José Lépez-Portillo to Miguel de la Madrid in 1982 and with PRONASOL $^{8}$ when Carlos Salinas was succeeded by Ernesto Zedillo in 1994. In the end, however, Progresa survived. It only lost its name. In fact, rather than discard the program, Fox's administration increased coverage from 2.3 to 4.2 million households and added semi-urban and urban localities. The program not only survived the transition from Zedillo to Fox, but from the latter to Felipe Calderon in 2006. Clearly, Oportunidades has proven to be much more shielded from politics than any anti-poverty program in the past.

With time, Progresa/Oportunidades has become one of the most-renowned CCTs around the world. Celebrated by academics, ${ }^{9}$ multilateral organizations, policy-makers and the media alike, it is constantly used as a model of a successful anti-poverty program. What accounts for Progresa/Oportunidades' success? What are the factors which explain its notoriety and prestige? Why was the program not scrapped in 2002? Here it will be argued that the transformation of well-trained scholars into influential practitioners played a fundamental role in promoting a new conceptual approach to poverty reduction, ensuring the technical soundness and effectiveness of the program's design, incorporating rigorous impact evaluations as part and parcel of the program's design, persuading politicians to implement and keep the program in place and engaging in an ongoing communication with the scholarly community both in Mexico and abroad. This conclusion is based, to a large extent, on the author's personal experience when she was Senior Advisor and Chief of the Poverty and Inequality Unit at the Inter-American Development Bank (IDB) (1997-2001). In this capacity, the author was able to witness first-hand the evolution of the program and was instrumental in facilitating the first-round of impact evaluation of Progresa and promoting CCTs more broadly.

The paper is organized as follows. The next section will explore how research influenced the program's design, including its impact evaluation component. Section 3 analyzes how impact evaluation studies contributed to the program's success and political survival as well as its

\footnotetext{
${ }^{7}$ Instituto Mexicano del Seguro Social - Coordinación General del Plan Nacional de Zonas Deprimidas y Grupos Marginados (Mexican Institute of Social Security - General Coordination of the National Plan for Depressed Areas and Marginalized Groups). For more information visit the website of the Mexican Institute of Social Security: http://www.imss.gob.mx/programas/oportunidades/historia.htm 8 Programa Nacional de Solidaridad (National Solidarity Program)

${ }^{9}$ See, for example, articles by such internationally renowned scholars as Nobel Laureate Gary Becker in Business Week, Princeton's economist Alan Krueger in The New York Times, and Francis Fukuyama in the Wall Street Journal (Behrman, 2007). Another indicator of the visibility of Progresa/Oportunidades is provided by the number of hits on Google: about 1,420,000 on Google and about 12,100 on Google Scholar (Behrman, 2007).
} 
international notoriety. The final section will elaborate on which conditions made it possible for research results to take such center-stage in Mexico's signature anti-poverty program.

2. Recognizing the Limitations of Price Subsidies as a Tool to Fight Poverty, the Development of a New Approach to Poverty Reduction and the Design of Progresa/Oportunidades: the Role of Research, Scholars and Scholars-Practitioners

Aimed at reducing current and future poverty, Oportunidades transfers cash to eligible poor families as long as conditions_-also known as co-responsibilities_-are fulfilled. Oportunidades has three main components: education, nutrition, and health. The education component grants cash transfers based on school attendance; in-kind transfers of school supplies, which are sometimes given as an additional cash transfer; and scholarships for each year of high school that students complete that can be retrieved from their interest bearing account only if the student graduates by the age of 22. The nutrition and health components offer cash and in-kind transfers (nutritional supplements, vaccinations, preventative treatments, and so forth), based on regular visits to a health clinic and the mother and teenagers' attendance at health talks. In 2007, a fourth component was added to provide beneficiaries with a subsidy for their electricity bills ${ }^{10}$

Beneficiaries are selected based on a multi-stage targeting process that depends, among other things, on a composite deprivation index known as the "Sistema Unico de Puntajes" (SUP). The formula of the SUP is kept confidential but it essentially takes into account dwelling characteristics as well as the age and gender composition of the household (in particular, the presence of children and elderly members). ${ }^{11}$ The average monthly transfer in 2005 was about US $\$ 35^{12}$ and equivalent to approximately 25 percent of eligible rural households' average monthly income. The program's size is significant in terms of beneficiaries yet inexpensive in terms of cost. By 2008, Oportunidades granted benefits to 4.3 million families (over 20 percent of the Mexican population) and its budget was equal to 0.35 percent of GDP and 1.5 percent of public expenditures. ${ }^{13}$ The program had come a long way since it was piloted in 1997 when it had a budget of 0.02 percent of GDP to serve around 300,000 families.

\footnotetext{
${ }^{10}$ For details, see Greenspun (2011), table 4.

11 See Levy (2006) for details.

12 This figure can increase in families with school-age children. In 2005, Progresa/ Oportunidades granted monetary benefits and benefits in-kind equivalent to direct monetary monthly assistance of US\$44.30 per family (Levy 2006).

${ }^{13}$ Greenspun (2011).
} 
Along with the smaller scale Bolsa Escola in Brazil, Progresa/Oportunidades pioneered an innovative "technology" in anti-poverty policy. It demonstrated that i. transferring cash to millions of households even in geographically remote areas was feasible and ii. cash transfers could be effectively combined with improvements in health, education and nutrition of poor household's children. What gave rise to this innovation? What was the role of research?

Behrman (2007) concludes that "the initial formulation of the program was motivation to basically make transfers to poor households more effective (with less leakage) and better targeted by shifting from effectively inframarginal in-kind food transfers to cash transfers conditional on behaviors affecting all household members (through the conditionalities on health and nutrition related checkups), with the schooling conditionalities added late in the pre-program development phase (Levy 2006)." Research had established that targeted price subsidies such as tortilla and other food price subsidies in Mexico were not really helping the poorest of the poor. ${ }^{14}$ In addition, there was not even a clear sense of whether these subsidies contributed to higher nutrition outcomes among the poor. Even though the targeted tortilla (Tortibono) and milk (Liconsa) subsidies were progressive in relative terms (that is, the value of the subsidy in proportion to household income varied inversely with the latter), they were costly to operate and regressive in absolute terms (that is, the per capita value of the subsidy varied directly with household income) primarily because the beneficiaries were urban households. The latter meant that the non-poor received a higher share of the subsidy than the poor: the poorest population quintile received just 8.5 percent and 17.3 percent of the milk and tortilla subsidies, respectively.

Spearheaded by Santiago Levy (President Zedillo’s Undersecretary of Budget in the powerful Secretaria de Hacienda y Credito Publico (SHCP)), since December 1994 the country's anti-poverty spending became increasingly more targeted to the poor. ${ }^{15}$ The generalized (urban) consumer subsidy was gradually replaced by targeted tortilla (Tortibono) and milk (Liconsa) subsidies. Even though the share of the benefits accruing to the poorest quintile rose, these two programs were costly to operate and mainly urban, and even within urban areas they were not really targeted to the poorest households. The general tortilla subsidy was scrapped in 1998, and resources previously used for food subsidies were reallocated to rural areas through Progresa. This shift transformed the

\footnotetext{
14 World Bank on targeted transfers; Lustig in Cornelius, Craig and Fox; Kehoe and Serra-Puche (1986) on price subsidies cited in Lustig (1997); and Scott (2002).

15 The concept of targeted spending as an explicit category reported separately was introduced in official public sector accounts in the mid 1990's.
} 
broadly neutral distribution of government spending on food subsidies into a highly progressive one: the share of government resources accruing to the poorest decile increased from 8 in 1994 to 33 percent in 2000. (Figure 1) 
Figure 1

Distribution of food subsidies and undernourished children (low height/age) by per

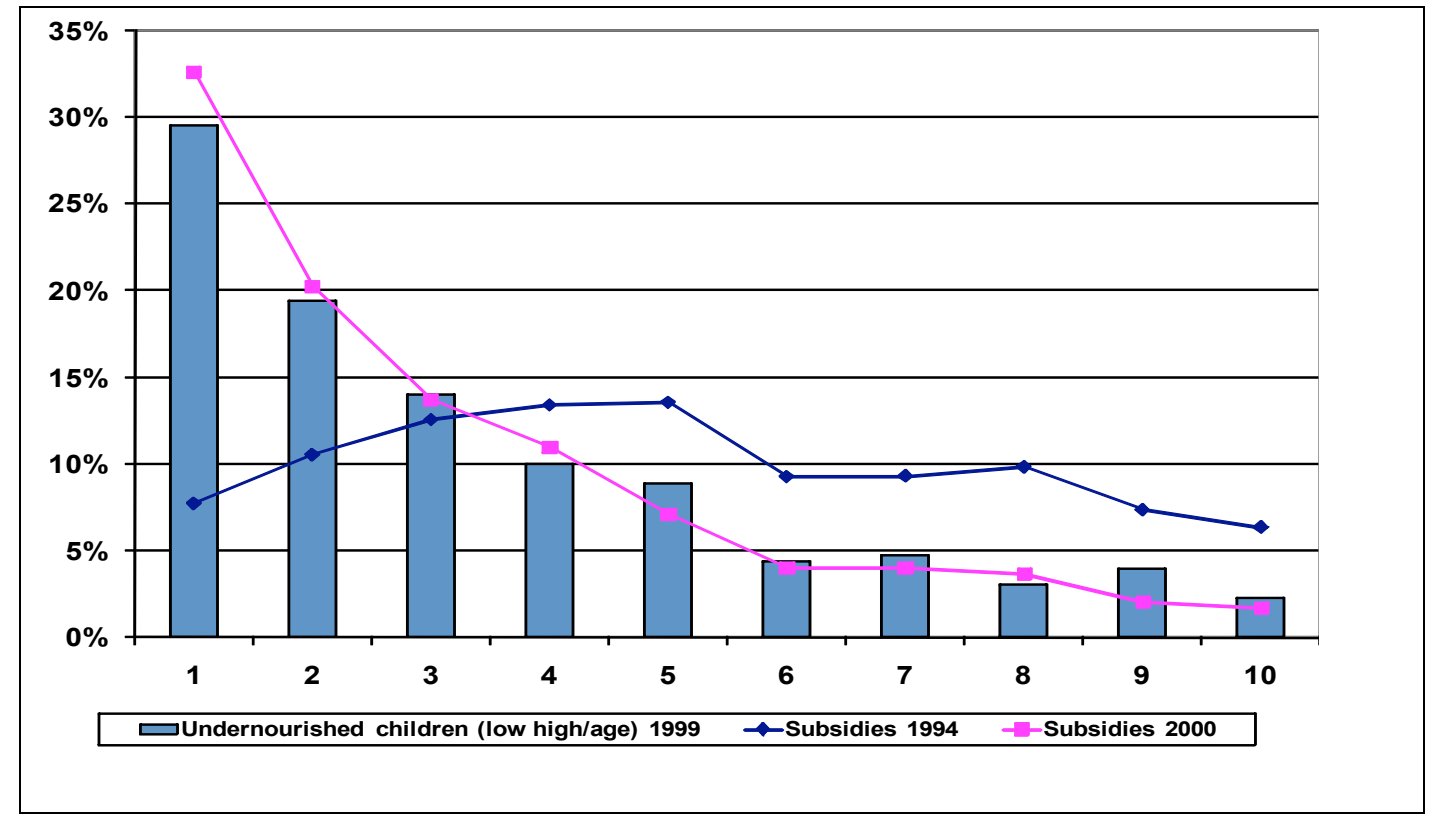

Source: Scott (2004), Graph 17; based on EncuestaNacional de Nutrición 1988 and 1999.

Research had also established that paying attention to targeting mechanisms to avoid leakages and negative incentives was crucial. Finally, research had also been instrumental in showing the importance of intra-household dynamics and why it was better to grant resources to women/mothers than men/fathers for the transfers to be more effective in building poor children's human capital. According to Behrman (2007), Santiago Levy suggested that research had influenced the design of Progresa regarding: "(a) the ineffectiveness of previous food aid strategies (e.g., not well targeted, inframarginal income effects, high transaction and bureaucratic costs of in-kind programs; limitations of supply-side interventions), (b) the importance of intrahousehold allocations and therefore the need to make programs be conditional on benefits received by all household members, (c) related gender concerns, and (d) that food problems are not the same as nutritional problems.... [T] he most important explicit studies that affected his thinking were Besley and Kanbur $(1988,1990)$ on food subsidy programs, Haddad and $\operatorname{Kanbur}(1989,1990)$ on the extent of intrahousehold inequalities in the distribution of nutrients, Behrman and Deolalikar $(1987,1988)$ on low nutrient elasticities with respect to income, Schultz on schooling, Castañeda on targeting using the SISBEN in Colombia, and Streeten $(1989 \mathrm{a}, \mathrm{b})$ on the poverty and on the relations between health and 
nutrition.” (Behrman, 2007, p. 17) In fact, Levy’s World Bank paper on "Poverty Alleviation in Mexico" (1991b, 1994) that included many of the ideas that underlay the development of Progresa features 71 references with named authors. ${ }^{16}$

Another key figure in bringing scholarly work into the design of Progresa/Oportunidades was the late José "Pepe" Gómez de León, the program's first Director. ${ }^{17}$ The author recollects his keen concern in developing a targeting method that would minimize perverse incentives such as making beneficiary households work less so that they would not pass the income threshold that assured them of benefits. This gave rise to the SUP, the confidential formula used by Progresa/Oportunidades to select beneficiaries. A quantitative demographer/sociologist by training, Gómez de León directly contributed to the formalization (i.e., the mathematical formulation) of the targeting mechanism. Gómez de León knew about the research by such distinguished scholars as Behrman, Gertler and Schultz, as well as other outstanding work at the International Food Policy Research Institute (IFPRI) and the World Bank, both in Washington, DC. He was keen in making the program efficient, cost-effective and as apolitical as possible. ${ }^{18}$

For close to four years, Gómez de León dedicated himself wholeheartedly to this aim, combining visits to the field in dire circumstances, coordinating disparate government agencies, shielding the program from predatory politicians, and promoting high quality research on the program's effects (including his own).

\footnotetext{
16 The references that Levy (2007) cites as key in his thinking regarding his contribution to the development of Progresa cite other previous scholarly work as well. For example, Besley and Kanbur cite Scobie (1983); Behrman and Deolalikar (1987) cite Pinstrup-Andersen and Caicedo (1978) and Timmer and Alderman (1979) plus a number of citations to Behrman; Behrman and Deolalikar (1988) cite Alderman (1984), Alderman and Von Braun (1984), Pinstrup-Andersen (1985), von Braun and de Haen (1983) - plus eight citations to studies by Schultz and a number of citations to studies by Behrman; Streeten (1989a) refers to four studies by Lipton (1983a, b, 1985, 1988a) and also refers to a study by Schultz to which Lipton (1988a) refers; and Streeten (1989b) refers to International Food Policy Research Institute (1986) and Reutlinger and Alderman (1980) in addition to one of the Lipton studies (Behrman, 2007). The relatively large number of citations spanning a period of 10-15 years suggests the field of anti-poverty analysis had built a "critical mass" of knowledge ready to be applied in practice.

${ }^{17}$ Gómez de León was director of the Progresa from 1997 to 2000 when he died of cancer (melanoma).

18 Behrman (2007) concludes that although he had “... not found any citations by Gómez de León in his studies before PROGRES $A$ was initiated to research by the IFPRI evaluation team members or IFPRI more broadly, ... two of his 1999 studies with Parker (Gómez de León and Parker 1999a, b), however, do cite seven studies by IFPRI staff or by the evaluation team members that were written before the initiation of PROGRESA (in addition to studies that came out of the evaluation): Haddad, Hoddinott, and Alderman (1997), Haddad and Reardon (1993), Quisumbing (1994), and Schultz (1990) on gender and intrahousehold allocations; Heckman, Ichimura, and Todd (1997) and Heckman and Todd (1996) on propensity score matching estimators and evaluation; and Newman, Rawlings, and Gertler (1994) on using randomization for evaluation of social policies in developing countries. This suggests that, although Gómez de León did not cite these studies before 1997, Gómez de León and Parker in 1999 at least thought that these studies captured important dimensions of the evolving conventional wisdom on these topics at the time that Gómez de León was engaged in developing PROGRESA.” (Behrman, 2007, p. 18)
} 
Very early on, Gómez de León recognized that the program's ability to survive political attacks would depend on demonstrating Progresa's success in achieving its goals through rigorous external evaluations undertaken by internationally recognized scholars. As a result, “... PROGRES $A$ incorporated data collection and systematic evaluation as an integral component from the start, with an initial experimental design in rural areas with random assignment for the first 18 months of treatment among 506 rural communities (320 with treatment starting in 1998, 186 initial controls with treatment starting in 2000) with over 24,000 households and over 120,000 individuals in the evaluation sample over the 1997-2000 period and with subsequent control samples selected through propensity score matching (PSM) in both rural and urban areas. Indeed one major reason that PROGRES $A$ is so wellknown has been the centrality of efforts at serious evaluation from the start — in contrast to other ... anti-poverty and human resource investment programs (particularly in Brazil) on which information has not been collected to permit systematic evaluation.” (Behrman, 2007, p. 3)

The author recalls a conversation with Gómez de León in 1997, right before or around the time she became Senior Advisor on Poverty and Chief of the Poverty and Inequality Unit of the IDB in September of that year. During this conversation, the author and Gómez de León agreed that it was essential to put in place an independent, high quality evaluation of the program to help improve its performance and political resiliency. This gave rise to the organization of a workshop convened by the author and held on December 10,1997 at the IDB. This meeting set the stage for the subsequent comprehensive evaluation of Progresa by IFPRI.

Behrman's account of how this came about may be illustrative: Apparently Nora Lustig, a member of the IFPRI Board of Trustees in 1994-97 and Senior Advisor on Poverty and Chief of the Inequality Unit of the Inter-American Development Bank in 1997-2001, played a major role in facilitating the conversation between IFPRI and PROGRESA about IFPRI undertaking the evaluation (Coady 2007, Haddad 2007, Lustig 1995, 1997a,b, 2007, Parker 2007, Schultz 2007). The first documentation that I can find of that contact is an e-mail of 21 June 1995 of Lustig (1995) to Lawrence Haddad at IFPRI apparently responding to an inquiry by Haddad about a staff member working with Santiago Levy who had contacted Haddad about evaluating a Mexican pilot food stamp program (a pilot program for PROGRESA) in which Lustig says that she had mentioned Haddad's name to Levy's Chief of Staff several months earlier. ... On November 11, 1997, Lustig (1997a) sent an e-mail to Haddad, Gary Burtless at the Brookings Institute [sic] and 13 staff members of the World Bank (mostly empirical micro economists and policy analysts) inviting them to a workshop on December 10, 1997 to be held at the Inter-American Development Bank under the sponsorship of the Poverty and Inequality Advisory Unit (of which Lustig was the chief) "to discuss evaluation schemes of the recently launched target program in Mexico called PROGRESA" (she also noted that "The workshop will start with a presentation by Dr. Jose Gomez de Leon, the Director of PROGRES A" and provided a brief summary of the program).... On December 3, 1997, Lustig (1997b) sent an e-mail addressed to Lawrence Haddad, Jere Behrman, Paul 
Gertler, Paul Schultr, and James Heckman ... enclosing the program for the meeting on December 10, 1997, and further information and asking for references regarding these individuals' expertise. Haddad, Ruel, and Quisumbing from IFPRI (Haddad 1998), Bebrman, Gertler, and Schultz all attended the meeting (Heckman did not but asked Petra Todd to attend in his place, which she did) and subsequently became increasingly involved (under Haddad's leadership and with substantial input from other IFPRI staff) in the development of the IFPRI proposal for undertaking the evaluation on which agreement was reached in the late summer of 1998. (Behrman, 2007, p. 19)

3. Impact Evaluation and its Influence on Progresa's Political Survival and International Standing

IFPRI was contracted by the Mexican government to undertake the initial evaluation of Progresa in 1998-2000, followed by a series of contracts for subsequent evaluations to date by the Mexican Instituto de Nutrición y Salud Pública. In addition, the government has been willing to share the rich database of Progresa/Oportunidades surveys with scholars, including students working on their theses and dissertations. As a result, Progresa/Oportunidades is probably one of the most studied programs in the developing world. It is important to note that a substantial portion of the research on the program is published in top refereed journals and thus it has been consistent with combining practical relevance with succeeding in academia.

Many of the impact evaluation studies found that the program has had significant (in the statistical sense) positive impacts on education and health. ${ }^{19}$ Comparing post-primary enrollment before the program (1996-97) and after the program (2002-03), one study reported an average increase of 24 percent in rural areas. ${ }^{20}$ Of note was enrollment in secondary education in rural areas, which rose by 11 percent for girls and 7.5 percent for boys two years after the program was launched. ${ }^{21}$ Another study found that demand for health services among Progresa/Oportunidades beneficiaries was 67 percent higher than demand in communities not participating in the program. ${ }^{22}$ Infant mortality was found to fall at a rate 11 percent higher among beneficiaries compared to nonbeneficiaries. $^{23}$ Another study estimated a reduction of 11 percent on maternal mortality and a 2 percent reduction in infant mortality in rural communities compared to those not in the program. ${ }^{24}$

\footnotetext{
${ }^{19}$ See, for example, Parker (2005) and Schultz (2000) and references cited in Esquivel, Lustig and Scott (2010) and Greenspun (2011).

${ }^{20}$ Parker (2005).

${ }^{21}$ Schultz (2000).

22 Bautista and others (2004).

${ }^{23}$ Barham (2005).

${ }^{24}$ Hernández and others (2003).
} 
Improved access to education and these health gains may help explain recent changes in the relative earnings of the low-income workers. Better access to health services may have improved the productivity of low-skilled workers: for example, improved access to health services may have translated into fewer days of work missed due to illness. Better access to health services may have also improved the cognitive development of children in poor households, thereby improving their educational achievement and productivity. ${ }^{25}$

In December 2001, when Vicente Fox took office, Progresa faced a serious risk of being scrapped. The author had an opportunity to meet with Fox's Minister of Social Development, Josefina Vázquez Mota, very early in the administration. Vázquez Mota was skeptical of Progresa. A good number of social policy analysts (including the author) wrote columns on the importance of keeping Progresa, citing the impact evaluation results as evidence of its success in reducing poverty and improving school attendance and health outcomes among the extreme poor. In the end, the program survived with a vengeance. Under Fox's administration Progresa-re-baptized Oportunidades — was expanded to semi-urban and urban areas and the number of beneficiaries increased from 2.3 to 4.2 million households. Miguel Székely, a former researcher at the IDB, was appointed Undersecretary in the Ministry of Social Development and the new director of Oportunidades was a member of the late Gómez de León’s team.

In addition, Progresa/Oportunidades soon became an example for other countries to emulate. Although Brazil had been experimenting with a similar program since the mid-1990s (Bolsa Escola), James Wolfensohn (former president of the World Bank) invited Santiago Levy to meet with President Lula da Silva to discuss alternative approaches to poverty reduction. With inputs from Brazilian scholars and scholars-practitioners, Lula's government eventually decided to combine several of its programs into one integrated approach and Bolsa Familia was born. Programs similar to Progresa (some large-scale and some small) now exist in most of Latin America and beyond. While in 1997 there were really only three programs that would qualify as CCTs, by 2008 the number grew to $28 .^{26}$ (Figure 2) The World Bank, Inter-American Development Bank, IFPRI and MIT's Abdul Latif Jameel Poverty Action $\mathrm{Lab}^{27}$ and the governments themselves--among

\footnotetext{
${ }^{25}$ See, for example, Lustig $(2007,2007 a)$.

${ }^{26}$ See Fiszbein et al. (2009).

${ }^{27} \mathrm{See}$ http:/www.povertyactionlab.org/search/apachesolr_search/conditional $\% 20 \mathrm{cash} \% 20 \operatorname{transfer} \% 20$ ?filters=type:evalua $\underline{\text { tion }}$
} 
others - have been instrumental in collecting and disseminating the knowledge acquired both through research and practical experience from one place to the other.

Figure 2 - Conditional Cash Transfer Programs in the World: 1997 and 2008
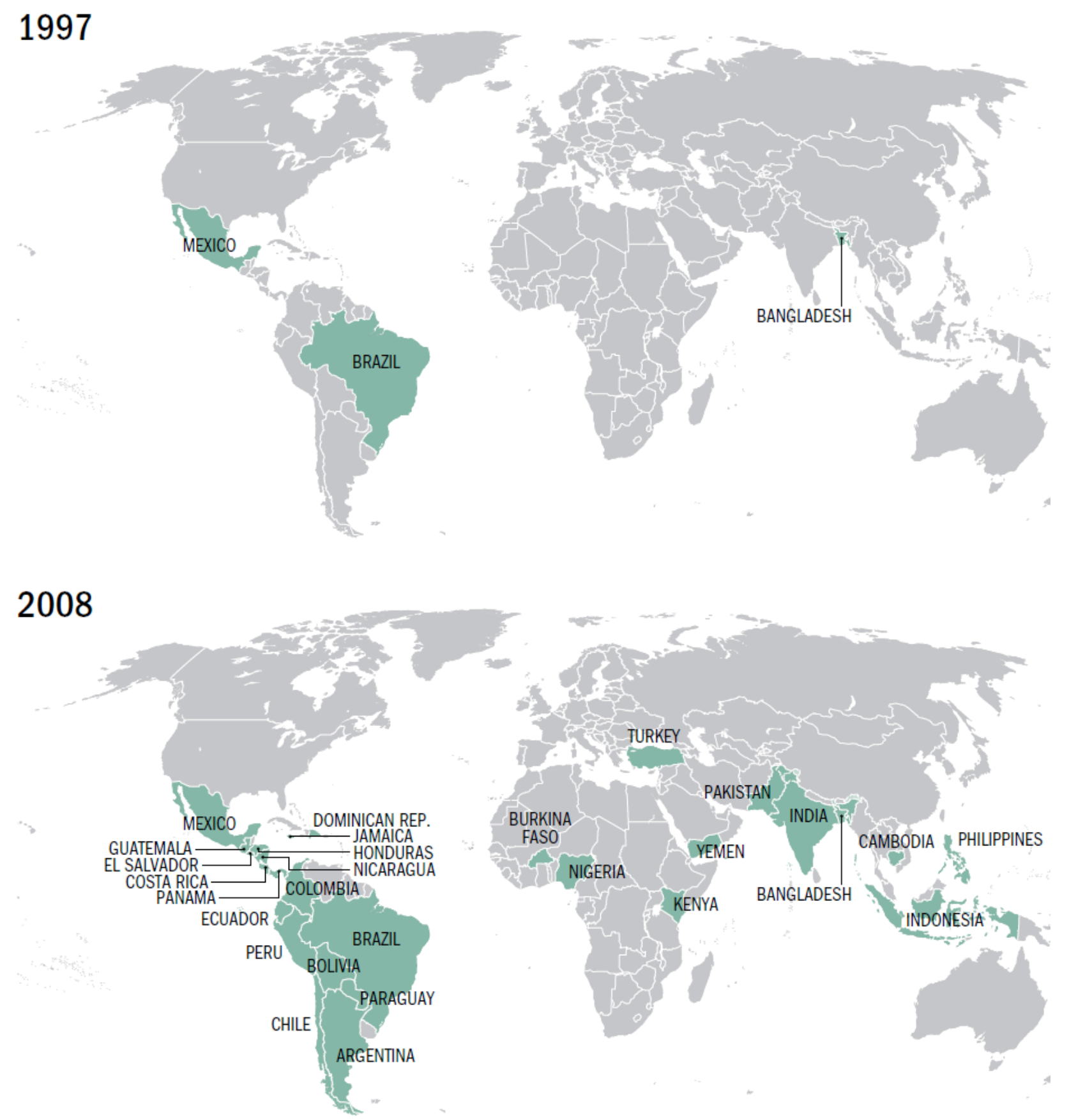

Source: Fiszbein et al. (2009), Figure 1, page 4. 


\section{Lessons from Progresa/Oportunidades}

Scholars and scholarly research have been part of Progresa/Oportunidades since its inception. The above account suggests that a key factor was that the practitioners who had a key role in the design, implementation and evaluation of the program had been scholars themselves at some point in their professional careers. President Zedillo had been a researcher at the Bank of Mexico upon completing his Ph.D. in Economics at Yale. Zedillo had great respect for sound and relevant economic theory and empirical analysis. He was very critical of Mexico's existing consumer and producer subsidy schemes and was quickly persuaded by the arguments put forward by Santiago Levy and others regarding the implementation of an anti-poverty program as Progresa. From previous experience, Zedillo knew that the program's ability to survive beyond his sexenio would depend on not making it his "personal" initiative (as it had happened with Pronasol under Salinas). In addition, Zedillo must have thought that keeping the program independent from multilateral organizations would increase its chances to survive politically as well.

Santiago Levy, the program's intellectual architect in its pilot phase, has a Ph.D. from Boston University and for many years was an academic at the Instituto Tecnológico Autónomo de Mexico (ITAM) and later at Boston University itself. Before joining the Mexican government in the early 1990s, Levy spent some time doing research on poverty and NAFTA at the World Bank. José Gómez de León, had a doctorate in demography and worked as an academic at El Colegio de México for several years. Nora Lustig, who has a Ph.D. in Economics from the University of California, Berkeley, had also been an academic at El Colegio de México before joining the Brookings Institution in 1989; from Brookings she joined the IDB in 1997. Miguel Székely has a Ph.D. from Oxford University and worked in the research department at the IDB. Zedillo first met Levy and Gómez de León when he was in the research department at the Bank of Mexico in the late 1970s (and perhaps even earlier). Lustig met Zedillo, Gómez de León, Levy and Székely when she was at El Colegio de México in the 1970s and 1980s. All five shared a solid academic background, a high regard for scholarly work and a genuine concern for making anti-poverty programs effective. All five were scholars or researchers who became practitioners; and, to some extent, all five were practitioners who continued to do scholarly work (and some of them became scholars again).

The presence of scholars who became practitioners is probably a fundamental reason why research played an important role in identifying the limitations of existing programs, promoting a new approach to poverty reduction, and determining the design and adaptation of 
Progresa/Oportunidades over time. The existing research -impact evaluation studies in particularhad a significant impact on the program's political survival. Whether the presence of scholars who become practitioners is a necessary or sufficient condition in other settings for knowledge and research to influence policy is a question for further research. In the case of macroeconomic policy, it is quite common to see relatively close exchange between scholarly work, scholars and practitioners. Central Banks and Ministers of Finance the world over have former academics among their staff. However, the outcomes of such "intimacy" between research and policy are not always felicitous. The negative consequences of supply-side economics and financial liberalization are two good examples of cases where it would have been better for the advice of scholars to fall into policymakers' deaf ears. 


\section{$\underline{\text { References }}$}

Alderman, Harold. 1984. "The effects of income and food price changes on the acquistion of food by low-income households." International Food Policy Research Institute, Washington, DC (draft).

Alderman, Harold and Joachim von Braun. 1984. "The effects of the Egyptian food ration and subsidy system on income distribution and consumption." Research Report 45. Washington, DC: International Food Policy Research Institute.

Barham, Tania. 2005. "Providing a Healthier Start to Life: The Impact of Conditional Cash Transfers on Infant Mortality.” Ph.D. dissertation/working paper, Department of Agriculture and Resource Economics, University of California Berkeley.

Bautista, Sergio and others. 2004. "Impacto de Oportunidades en la Morbilidad y el Estado de Salud de la Población Beneficiaria y en la Utilización de Servicios de Salud: Resultados de Corto Plazo en Zonas Urbanas y de Mediano Plazo en Zonas Rurales.” In Evaluaciónexterna de impacto del programa Oportunidades 2004,Tomo II,Salud, edited by Bernardo Hernández and Mauricio Hernández. México D.F.: CIESAS/INSP.

Becker, Gary S. Nov 22, 1999. "Bribe' Third World parents to keep their kids in school.” Business Week (Industrial/Technology Edition). New York: 15.

Behrman, Jere R. December 2007. "Policy-Oriented Research Impact Assessment (Poria) Case Study on the International Food Policy Research Institute (IFPRI) and the Mexican Progresa AntiPoverty and Human Resource Investment Conditional Cash Transfer Program." Impact Assessment Discussion Paper No. 27, Washington DC: IFPRI.

Behrman, Jere R. and Anil B. Deolalikar. 1987. "Will developing country nutrition improve with income? A case study for rural South India." Journal of Political Economy 95 (3, June): 108-138.

1988. "Health and nutrition." In Handbook on economic development, vol. 1, eds. Hollis B.

Chenery and T.N. Srinivasan, pp. 631-711. Amsterdam: North Holland Publishing Co.

Besley, Timothy and Ravi Kanbur. 1988. "Food subsidies and poverty alleviation." The Economic Journal 98 (392): 701-719.

. 1990. “Principles of Targeting.” Working Paper Series 385. Washington, DC: World Bank.

Coady, David. 2007. "Interview Related to IFPRI Evaluation of the PROGRESA/Oportunidades program." Interview By Jere Behrman in Appendices of Behrman, Jere R. December 2007. "PolicyOriented Research Impact Assessment (Poria) Case Study on the International Food Policy Research Institute (IFPRI) and the Mexican Progresa Anti-Poverty and Human Resource Investment Conditional Cash Transfer Program.” Impact Assessment Discussion Paper No. 27, Washington DC: IFPRI.

Esquivel, Gerardo, Nora Lustig and John Scott. 2010. "Chapter 7: Mexico: A Decade of Falling Inequality: Market Forces of State Action? In Declining Inequality in Latin America: A Decade of Change?, edited by Luis F. López-Calva and Nora Lustig, 175-217. Washington, DC: Brookings Institution 
Press; New York: United Nations Development Programme.

Fiszbein, Ariel and Norbert Schady with Francisco H.G. Ferreira, Margaret Grosh, Nial Kelleher, Pedro Olinto and Emmanuel Skoufias. 2009. Conditional Cash Transfers: Reducing Present and Future Poverty. A World Bank Policy Research Report, Washington, DC: The World Bank.

Fukuyama, Francis. Feb 1, 2007. "Commentary: Keeping up with the Chavezes." The Wall Street Journal. New York: A17.

Gómez de León, José and Susan Parker. 1999a. "The impact of anti-poverty programs on labor force participation: The case of Progresa in Mexico.” Mexico City, Mexico: PROGRESA.

1999b. "The impact of anti-poverty programs on female labor force participation and women's status: The case of Progresa in Mexico." Paper prepared for the 1999 IUSSP Conference on Women in the Labor Market. PROGRESA, Mexico City.

Greenspun, Samantha. 2011. “Assessing Mexico’s Anti-poverty Program 'Oportunidades:' Combining and Comparing Objective and Interview-based Indicators." Master of Arts Thesis. New Orleans, LA: Tulane University.

Haddad, Lawrence. 1998. Progresa. E-mail communication of February 11, 1998 to 20 IFPRI staff members.

. 2007. "Interview Related to IFPRI Evaluation of the PROGRESA/Oportunidades program." Interview By Jere Behrman in Appendices of Behrman, Jere R. December 2007. "Policy-Oriented Research Impact Assessment (Poria) Case Study on the International Food Policy Research Institute (IFPRI) and the Mexican Progresa Anti-Poverty and Human Resource Investment Conditional Cash Transfer Program.” Impact Assessment Discussion Paper No. 27, Washington DC: IFPRI.

Haddad, Lawrence and Ravi Kanbur. 1989. "How Serious is the Neglect of Intrahousehold Inequality?” Working Paper 296. Washington, DC: World Bank.

1990. “Are Better-off Households More Unequal or Less Unequal.” Working Paper Series 373 (March). Washington, DC: World Bank.

Haddad, Lawrence, John Hoddinott and Harold Alderman, eds. 1997. "Intrahousehold resource allocation in developing countries: Models, methods, and policy." Baltimore, Maryland: The Johns Hopkins University Press.

Haddad, Lawrence and Thomas Reardon. 1993. "Gender bias in the allocation of resources within households in Burkina Faso: A disaggregated outlay equivalent analysis." Journal of Development Studies 29 (2): 260-276.

Heckman, James, Hidehiko Ichimura and Petra E. Todd. 1997. "Matching as an econometric evaluation estimator: Evidence from evaluating a job training programme." Review of Economic Studies 64: 605-654.

Heckman, James and Petra E. Todd. 1996. "Assessing the performance of alternative estimators of 
program impacts: A study of adult men and women in JTPA.” Technical Report. Chicago, Illinois: University of Chicago.

Hernández, Bernardo and others. 2003. "Evaluación del Impacto de Oportunidades en la Mortalidad Materna e Infantil.” In Evaluación Externa del Impacto del Programa Oportunidades 2003, vol. 2, edited by Bernardo Hernández Prado and Mauricio Hernández Ávila. Cuernacava, México: Instituto Nacional de Salud Pública.

International Food Policy Research Institute (IFPRI). 1986. “Report 1986.” Washington, DC: IFPRI.

Kehoe, Timothy J. and Jaime Serra-Puche. 1986. "A General Equilibrium Analysis of Price Controls and Subsidies on Food in Mexico." Journal of Development Economics Vol 21, No 1 (April): 65-87.

Krueger, Alan B. May 2, 2002. "A model for evaluation the use of development dollars south of the border." New York Times. New York: C2.

Levy, Santiago. 1991. " Poverty alleviation in Mexico.” Policy Research and External Affaire Working Paper 679. Washington, DC: World Bank.

. 1994. "La pobreza en Mexico." In Causas y políticas para combatirla, ed. F. Vélez. La pobreza en Mexico. ITAM y FCE: Mexico City: 15-112.

. 2006. Progress Against Poverty: Sustaining Mexico's Progresa-Oportunidades Program. Washington, DC: Brookings Institution Press.

2007. "Interview Related to IFPRI Evaluation of the PROGRESA/Oportunidades program." Interview By Jere Behrman in Appendices of Behrman, Jere R. December 2007. "Policy-Oriented Research Impact Assessment (Poria) Case Study on the International Food Policy Research Institute (IFPRI) and the Mexican Progresa Anti-Poverty and Human Resource Investment Conditional Cash Transfer Program.” Impact Assessment Discussion Paper No. 27, Washington DC: IFPRI.

Lipton, Michael. 1983a. "Poverty, undernutrition, and hunger." Staff Discussion Paper 597. Washington, DC: World Bank.

. 1983b. "Demography and poverty." Staff Discussion Paper 623. Washington, DC: World

Bank.

. 1985. “A problem in poverty measurement." Mathematical Social Sciences 10 (1): 91-97.

. 1988a. "Who are the poor? What do they do? What should we do?" Michigan State

University, East Lansing (draft).

Lustig, Nora. Jan 1986. "Food Subsidy Programs in Mexico." Working Paper No. 3, Washington, DC: IFPRI (International Food Policy Research Institute).

1994. "Solidarity as a Strategy of Poverty Alleviation." Chapter 5 in Transforming State Society

Relations in Mexico: The National Solidarity Strategy, edited by Wayne Cornelius, Ann L. Craig and 
Jonathan Fox. San Diego: Center for U.S.-Mexican Studies, University of San Diego: 79-96.

1995. Questionnaire workshop and other matters. E-mail communication of June 21 to Lawrence Haddad.

1997a. PROGRESA meeting invitation. E-mail communication of November 11 to Lawrence Haddad (IFPRI), Gary Burtless (Brooking Institution), and 13 World Bank

Researchers(judging from the e-mail addresses apparently including Charles Griffin, Margaret Grosh, C. Hamman, Jesko Hentschel, Emmanuel Jimmenez, Norman Hicks, Elizabeth King, Michael Walton, Judith McGuire, Julian Schweitzer, Kalanidhi Subbarao, Jacques van de Gaag, and P. Vieridaracunha).

. 1997b. PROGRESA meeting. E-mail communication of December 3 to Lawrence Haddad (IFPRI), Jere Behrman (University of Pennsylvania), Paul Gertler (University of California at Berkeley), James Heckman (University of Chicago), and T. Paul Schultz (Yale University).

2007. "Interview Related to IFPRI Evaluation of the PROGRESA/Oportunidades program." Interview By Jere Behrman in Appendices of Behrman, Jere R. December 2007. "Policy-Oriented Research Impact Assessment (Poria) Case Study on the International Food Policy Research Institute (IFPRI) and the Mexican Progresa Anti-Poverty and Human Resource Investment Conditional Cash Transfer Program.” Impact Assessment Discussion Paper No. 27, Washington DC: IFPRI.

. 2007a. "Investing in Health for Economic Development: The Case of Mexico," in Advancing Development - Core Themes in Global Economics, edited by George Mavrotas and Anthony Shorrocks, Palgrave Macmillan in association with the United Nations University-World Institute for Development Economics Research.

Newman, J., Laura Rawlings and Paul Gertler. 1994. "Using randomized control designs in evaluating social sector programs in developing countries." World Bank Research Observer 9 (2): 181201.

Parker, Susan. 2005. "Evaluación del Impacto de Oportunidades sobre la Inscripción, Reprobación, y Abandono Escolar.” In Evaluación Externa del Impacto del Programa Oportunidades 2004, edited by Bernardo Hernández Prado and Mauricio Hernández Ávila. Mexico: Instituto Nacional de Salud Pública.

. 2007. "Interview Related to IFPRI Evaluation of the PROGRESA/Oportunidades program." Interview By Jere Behrman in Appendices of Behrman, Jere R. December 2007. "Policy-Oriented Research Impact Assessment (Poria) Case Study on the International Food Policy Research Institute (IFPRI) and the Mexican Progresa Anti-Poverty and Human Resource Investment Conditional Cash Transfer Program.” Impact Assessment Discussion Paper No. 27, Washington DC: IFPRI.

Pinstrup-Andersen, Per and Elizabeth Caicedo. 1978. "The potential impact of changes in income distribution on food demand and human nutrition." American Journal of Agricultural Economics 60 (August): 402-415.

Pinstrup-Andersen, Per. 1985. "Food prices and the poor in developing countries." European Review 
of Agricultural Economics 12 (1/2): 69-85.

Quisumbing, Agnes. 1994. "Intergenerational transfers in Philippine rice villages: Gender differences in traditional inheritance customs." Journal of Development Economics 43 (2): 167-195.

Reutlinger, Shlomo and Harold Alderman. 1980. "The prevalence of calorie-deficient diets in developing countries.” World Development 8: 399-411.

Schultz, T. Paul. 1990. "Testing the neoclassical model of family labor supply and fertility." Journal of Human Resources 25 (4): 599-633.

. 2000. “The Impact of Progresa on School Enrollments: Final Report.” Washington:

International Food Policy Research Institute.

2007. "Interview Related to IFPRI Evaluation of the PROGRESA/Oportunidades program." Interview By Jere Behrman in Appendices of Behrman, Jere R. December 2007. "Policy-Oriented Research Impact Assessment (Poria) Case Study on the International Food Policy Research Institute (IFPRI) and the Mexican Progresa Anti-Poverty and Human Resource Investment Conditional Cash Transfer Program.” Impact Assessment Discussion Paper No. 27, Washington DC: IFPRI.

Scobie, Grant. 1983. "Food subsidies in Egypt: Their impact on foreign exchange and trade." Research Report 40. Washington, DC: International Food Policy Research Institute.

Scott, John. 2002. "Distribución de la ayuda alimentaria en México: La revolución de los noventa." Documento de Trabajo 240, División de Economía, CIDE.

. 2004. "Eficiencia redistributiva de los programas contra la pobreza en México." Documento de Trabajo 330, División de Economía, CIDE (Trabajo de Investigación comisionado por SEDESOL).

Streeten, Paul. 1989a. "Poverty: Concepts and measurement." Discussion Paper 6. Boston, Massachusetts: Boston University, Institute for Economic Development.

. 1989b. "Hunger." Discussion Paper 4. Boston, Massachusetts: Boston University, Institute for Economic Development.

Timmer, C. Peter and Harold Alderman. 1979. "Estimating consumption parameters for food policy analysis." American Journal of Agricultural Economics 61 (December): 982-994.

von Braun, Joachim and Hartwig de Haen. 1983. "The effects of food price and subsidy policies on Egyptian agriculture.” Washington, DC: International Food Policy Research Institute. 